Managing Talent 


\title{
TALENT MANAGEMENT
}

\author{
Series Editors: Vlad Vaiman and David Collings
}

This series focusses on talent management, one of the fastest growing areas of research in the areas of business and management. As a topic, it bridges a number of core management areas, including HRM, Organisational Psychology, Strategy, and International Business.

The series features monographs and edited collections exploring both research and practical perspectives on contemporary talent management. The main aim of the series is to provide a key outlet for scholars wishing to publish novel perspectives on talent and talent management from across disciplinary divides. It also provides an opportunity for those seeking to explore new and innovative issues and topics in this area in greater depth. The series will bring together emerging theoretical approaches with real-world practitioner perspectives from across a range of subjects in this field, including (but not limited to):

- Employer branding

- Talent analytics

- Global talent management

- Talent turnover

- Talent retention

- Talent development

- Talent and teams

- Distribution of performance

- Transferability of performance

- Contextual performance

- Performance and potential

- Talent management in SMEs

- Talent management in the public sector

- Talent management in developing economies

Titles in the series:

Talent Management in Small Advanced Economies, Snejina Michailova and Dana L. Ott 


\section{Talent Management Managing Talent: A Critical Appreciation}

\section{EDITED BY \\ STEPHEN SWAILES}

University of Huddersfield, UK

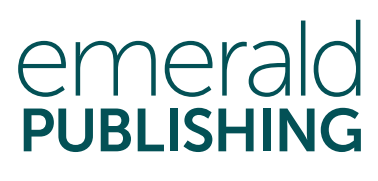

United Kingdom - North America - Japan - India - Malaysia - China 
Emerald Publishing Limited

Howard House, Wagon Lane, Bingley BD16 1WA, UK

First edition 2020

Copyright (C) 2020 Emerald Publishing Limited

\section{Reprints and permissions service}

Contact: permissions@emeraldinsight.com

No part of this book may be reproduced, stored in a retrieval system, transmitted in any form or by any means electronic, mechanical, photocopying, recording or otherwise without either the prior written permission of the publisher or a licence permitting restricted copying issued in the UK by The Copyright Licensing Agency and in the USA by The Copyright Clearance Center. Any opinions expressed in the chapters are those of the authors. Whilst Emerald makes every effort to ensure the quality and accuracy of its content, Emerald makes no representation implied or otherwise, as to the chapters' suitability and application and disclaims any warranties, express or implied, to their use.

\section{British Library Cataloguing in Publication Data}

A catalogue record for this book is available from the British Library

ISBN: 978-1-83909-094-3 (Print)

ISBN: 978-1-83909-093-6 (Online)

ISBN: 978-1-83909-095-0 (Epub)

ISOQAR certified

Management System,

awarded to Emerald

for adherence to

Environmental

standard

ISOQAR ISO 14001:2004. 


\section{Contents}

List of Figures vii

List of Tables ix

Contributors to this Volume $x i$

Foreword $x v$

Vlad Vaiman and David G. Collings

Introduction

Stephen Swailes 1

Chapter 1 Arbitrariness, Individuality, and the Absence of Work Identity in Talent Management

Billy Adamsen

Chapter 2 Social and Natural Constituents of Talent:

A Critical Appreciation

Stephen Swailes

Chapter 3 Some Critical Reflections on the Relevance of Talent Management Research

Eva Gallardo-Gallardo

Chapter 4 The Rhetoric, Politics and Reality of Talent Management: Insider Perspectives

Barbara Zesik

Chapter 5 Leadership Derailment: A Neglected Field in Talent Management

Suzanne Ross 
Chapter 6 The Missing Link: The Role of Line Managers and Leadership in Implementing Talent Management Peter Bos, Marian Thunnissen and Katja Pardoen

Chapter 7 How Inclusive Can Exclusive Talent Management Be?

Chapter 8 Critical Feminist Organisation Studies and Talent Management: Re-imagining Transnational, Intersectional and Postcolonial Agendas

Chapter 9 The Paradox of Attracting Key Talent in the Canadian Cannabis Industry: Turning Over a New Leaf 


\section{List of Figures}

Fig. 4.1. The Basic Logic of Talent Management 55

Fig. 4.2. The Reality of Talent Management 64

Fig. 6.1. The Role of Line Managers and Leadership in
Implementing Talent Management

Fig. 6.2. Full Model 101

Fig. 9.1. Nested Model of Macro-Micro Talent Management Factors 146 
This page intentionally left blank 


\section{List of Tables}

Table 5.1. Comparison of Derailment Potential Characteristics 76

Table 5.2. Gender Comparisons in Derailment Potential

Characteristics

Table 6.1. Means, SDs, and Correlations for All (Control)

Variables Included in This Study

Table 6.2. Standardised Coefficients and Significance Levels for Each Path Within Fig. 6.1

Table 6.3. $\quad R^{2}$ Values of the Variables in Fig. 6.1 
This page intentionally left blank 


\section{Contributors to this Volume}

Billy Adamsen is Associate Professor and Head of the Talent Lab for Crowdsourcing, Management \& Collective Intelligence in Denmark. He has published on a variety of subjects including management, sport and talent management, cognition and media, politics and media, the psychology of language, and knowledge management. In addition to his academic experience, he has worked as a manager and director in both national and international companies within the business and sports industries, as well as having been an Advisor for the Danish Prime Minister and Minister for Economics \& Business Affairs. He is author of Demystifying Talent Management - A Critical Approach to the Realities of Talent Management published by Palgrave in 2016 and Joint Editor of Managing Talent: Understanding Critical Perspectives published by Palgrave in 2019.

Fida Afouni is Associate Professor of Human Resource Management at the Olayan School of Business (OSB), American University of Beirut, Lebanon. She is also the Convenor of the Management, Marketing, and Entrepreneurship track at OSB. She obtained her PhD in Human Resource Management and Industrial Relations from Paris 1 Panthéon-Sorbonne University and was the recipient of the Sharjah award for the best doctoral thesis in administrative sciences in the Arab world for 2005. Her current research focusses on the interplay of human resource management, careers, and gender in the Arab Middle East with a particular interest in critically examining talent management practices in the region, HR policies in support of women's career development, as well as individuals' chosen career patterns and conceptualisations of career success. Her publications have appeared in several outlets, the most recent being in the Journal of Vocational Behavior, Human Resource Management Journal, and Business Research Quarterly.

Peter Bos, after graduating, worked at Utrecht University on the role of the social environment of long-term welfare recipients. Since 2012, he has been a Lecturer and Researcher at the School of Human Resource Management and Applied Psychology at Fontys University of Applied Sciences. His recent research focus is on leadership, in particular the role of line managers and how their actions (in) directly influence the development of employees.

Eva Gallardo-Gallardo is Associate Professor of Management at the Universitat Politècnica de Catalunya-BarcelonaTech, and Co-founder of the TechTalentLab. She previously held academic appointments at the Universitat de Barcelona, 
Universitat Oberta de Catalunya, and visiting appointments at University of Minho, Universitat de València, and HU Applied Sciences, Utrecht. Her research focusses on talent management, with a particular interest in understanding the formation and evolution of the field, its dynamics, and its conceptual boundaries. She has published papers in leading international outlets, such as Human Resource Management Review, International Journal of Human Resource Management, and the Journal of World Business. She has co-authored several chapters in international textbooks and one book.

Lotte Holck is Associate Professor at the Department of Organization, Copenhagen Business School. Her research explores the organisation of work and collaboration in different organisational settings and cultural contexts. With this as a general framework, her research pursues a critical approach to human resource management, human resource development, and talent management, exploring the impact of demographic, professional, and hierarchical differences. Methodologically, she applies longitudinal studies using intervention-based methods inspired by feminist activism in research as well as affective ethnography.

Yasmeen Makarem is Assistant Professor of Human Resource Development at the S. Olayan School of Business at the American University of Beirut in Lebanon. She received her doctorate from Texas A\&M University (TAMU) in May 2019 and was the recipient of the Distinguished Honor Graduate Award from TAMU for her academic achievements and leadership throughout her four-year doctoral studies. Her research explores human resource development practices in developing economies, with a particular focus on the theory and practice of career development. Her work has been published in several journals and academic conferences, including Human Resource Management Journal and Business Research Quarterly.

Deborah McPhee is Professor and Department Chair at Goodman School of Business at Brock University. She has over 25 years of Senior Human Resources Management (HRM) experience and has authored numerous refereed journal articles, HRM textbooks, book chapters, and case studies. Her research interests focus on HRM policies, attraction and retention of talent, ageing workers, and health and safety. She is currently involved in several funded projects concerning violence against women, the promotion of friendly pet shelter policies, matching immigrant newcomers and family businesses, and the resilience of migrant workers' health and safety in the cannabis industry. She has received two national awards for teaching and advancing HRM and health and safety as a field of study.

Beverly Dawn Metcalfe is Visiting Professor in the Centre for Inclusive Business and Women's Leadership at AUB, Lebanon. She has spent most of her academic career at the Global Development Institute at Manchester, and her work is primarily in the developing world especially MENA and Africa. Her research explores (1) human resource development, gender, and international development; (2) Islamic economics, Islamic feminisms, and development; and (3) Women's entrepreneurship and leadership in the Middle East. She has held Visiting 
Professor Positions at AUC and Helwan in Cairo, Egypt; Monash and Griffith Universities in Australia; and St. Petersburg State University, Russia. She has published in journals such as Human Relations and The International Journal of Human Resource Management. She has published one book Leadership Development in the Middle East and is completing texts on Responsible Islamic Finance and the SDGS and Women's Entrepreneurship and Development in the Middle East.

Katja Pardoen studied Strategic Human Resource Management at Tilburg University and is now an HR Consultant at the Fontys University of Applied Sciences. Her professional interest lies in talent development of employees and line managers. Since 2016, she has been affiliated to the Talent Management Research Group at the School of Human Resource Management and Applied Psychology at Fontys. She is also involved in a research project regarding lifelong learning in the context of work. She is an advocate of evidence-based human resource management and uses data from her research projects to improve and to innovate the talent management programme and the leadership programmes at Fontys.

Suzanne Ross is Senior Lecturer in Executive Education at Nottingham Business School, Nottingham Trent University. Her PhD focussed on executive talent, success, and derailment and her research interests span leadership and high performance and include resilience in leadership; women in leadership; and both the 'light' and the 'dark' sides of leadership from courageous, ethical, authentic leadership to toxicity, narcissism, and psychopathy in leadership. She was previously Talent Manager for a Global FTSE 100 company, and she is founder of 2thrive Consultancy, specialising in talent and leadership development, and is a qualified Executive Coach. Her consultancy work helps organisations to improve talent management practices, organisational, team and individual performance, and leadership effectiveness. At Nottingham Business School she is responsible for the HR Forum, a platform to engage HR and organisational behaviour professionals with latest thinking in the field.

Francine Schlosser is Odette Professor in Entrepreneurship and Innovation at the University of Windsor, Canada. Her research contributes to understanding how educators, employees, migrants, and employers can stimulate entrepreneurial readiness and innovative knowledge-based strategic involvement and manage mid and late career transitions. She has published in a range of leading journals and focusses on the development of innovative, work-integrated, and multinational experiential student learning experiences engaging students in the business community through multidisciplinary venture teams and consulting projects. She previously held the University of Windsor's Golden Jubilee Professorship and was Executive Director of the Entrepreneurship Practice and Innovation Centre.

Iben Sandal Stjerne is Assistant Professor at the Department of Organization, Copenhagen Business School. Her primary research interests lay in the intersection between transient forms of organising, temporality, and strategic management. Her research publications venture into topics such as careers in 
project-based industries, aesthetic selection practices, and the temporality and boundary work of temporary organisations. This has primarily been explored ethnographically, with an empirical focus on creative industries.

Stephen Swailes is Professor of Human Resource Management at Huddersfield Business School. His research interests have focussed on organisational commitment, management education, and team performance leading up to his current interests in talent management which focus in particular on ethics and power relations. He has published over 50 papers and several book chapters and is the Co-author of Organizational Change published by Pearson and Joint Editor of Managing Talent: Understanding Critical Perspectives published by Palgrave Macmillan.

Marian Thunnissen is Professor at the Utrecht School of Governance of Utrecht University and also at the School of Human Resource Management and Applied Psychology of Fontys University of Applied Sciences in Eindhoven. Her current research is focussed on the identification, attraction, and development of talent, in particular in the public sector. Her recent interests concern a 'team-based' talent management (TM) approach, the role of the line manager in TM, and the dilemmas and tensions organisations experience in developing and implementing TM. She is a leading author on TM and has co-authored several academic- and practice-oriented articles as well as book chapters on TM in knowledge-intensive organisations, the public sector, and academia. She is the Editor-in-Chief of the Dutch Journal of HRM.

Barbara Zesik has over 25 years' experience in a variety of senior and executive roles in Human Resources and Organisation Development in a number of industry sectors including IT, financial services, FMCG, global mobility, education, and digital marketing. Passionate about people and organisational development, her experience includes culture change, organisation design and restructuring, talent management, learning and development, mergers and acquisitions, as well as coaching and leadership development. She is a certified Master Practitioner and Trainer of NLP, holds an MSc in People and Organisation Development from the University of Sussex, and a Doctorate in Business Administration from the University of Surrey. 


\section{Foreword}

Talent Management is a new series of books edited and authored by some of the best and most renowned researchers in the field of talent management. As its name suggests, this Emerald series focusses on talent management, one of the fastest growing areas of research in the areas of business and management. As a topic, it bridges a number of core management areas, including human resource management, organisational psychology, strategy, and international business. This series features monographs and edited collections exploring both research and practical perspectives on contemporary talent management. The main aim of this series is to provide a forum for the publication of novel perspectives on talent and talent management from across disciplinary divides. It also provides the opportunity to explore new and innovative issues and topics in this area in greater depth.

This Emerald series, Talent Management, is intended to serve the growing market of global scholars and practitioners who seek a deeper and broader understanding of the role and importance of talent management in organisations. This series focusses on key areas of talent management practice as well as analyses at different levels from individual to societal. With this in mind, all books in this series provide a thorough review of existing research and multiple examples of companies around the world, wherever applicable. Given the nature of the subject at hand, the authors and editors of the books are global in their scope and the leading scholars in their respective areas. They bring exceptional knowledge of, and expertise in, the issues of talent management they address, and in some instances, the authors are the forerunners of their topics. We feel very fortunate to have such a distinguished group of academics involved in this series.

The second book in the series takes a welcome critical perspective on talent management and specifically provides a critique of the exclusive/elitist perspective which dominates the mainstream talent management literature. It also highlights a variety of pitfalls that the extant literature largely ignores. This book is appropriately titled Managing Talent: A Critical Appreciation, and it unearths and unpacks the most important questions which emerge from viewing mainstream approaches to talent management through a critical lens. In achieving its objectives, this volume takes an in-depth look at approaches to identifying, developing, deploying, and retaining talented employees in an organisation and to understanding the philosophies behind organisational talent management programmes. The contributors to Managing Talent: A Critical Appreciation offer an array of views that are aimed to inform further research and practice in talent management. 
It goes without saying that the publisher and editor are vital partners in making this series possible. In particular, we want to express our sincere gratitude for the work of our series editor, Niall Kennedy. He has always been very encouraging of the Talent Management series and instrumental in providing the necessary support to us and the authors and editors in the series. We also would like to thank the Senior Content Editor, Sophie Barr, for her help in making this series a success. Together we are all very excited about the Talent Management series and hope you find an opportunity to use and benefit from Managing Talent: A Critical Appreciation, as well as all other published and upcoming books in the series!

Vlad Vaiman, School of Management, California Lutheran University, USA

David G. Collings, DCU Business School, Dublin City University, Ireland

April 2020 


\title{
Introduction
}

\author{
Stephen Swailes
}

As it is with most management innovations, the literature on organisational talent management (TM) takes a largely mainstream, managerialist approach to explaining how and why organisations pursue TM and to understanding the effects that TM has on people and organisations. The field, however, rests on a number of core assumptions that are seldom questioned. Firstly, that the talented exist as a separate and identifiable organisational community. Secondly, that talented people can be identified with some reliability. Thirdly, that talent is scarce. Fourthly, that harnessing talent in the pursuit of excellence supports competitive advantage (Collings, Mellahi, \& Cascio, 2019; Meyers, 2019).

On the first and second assumptions, talent is plain to see in creative arts and sport, for example, but how true is it of business organisations? Indeed, exactly what is the talent so highly prized? Talent is often conflated with potential which is a highly subjective property of individuals (Silzer \& Church, 2009). Another factor is the role of luck in careers; perhaps better described as the ability to capitalise on chance events (Grimland, Vigoda-Gadot, \& Baruch, 2012). Recent modelling of normal distributions of talent shows that across a 40 year career the resulting distribution of success and capital follows a power law and that 'the most successful agents are almost never the most talented ones' (Pluchino, Biondo, \& Rapisda, 2018, p. 23). Resources given to successful employees may simply be following luck rather than talent; or at least there is a lot of luck behind success. This suggestion both supports and challenges recent research that performance in a range of occupations best fits a power distribution and not a normal distribution (Joo, Aguinis, \& Bradley, 2017). It supports it to the extent that a similar distribution of outcomes is found while it opens to question the cause of those outcomes; talent, luck or some combination thereof.

On the third assumption, scarcity narratives are predicated on the back of surveys that routinely prioritise executive concerns about skills shortages in labour markets (e.g., see SHRM, 2019) but this does not mean that employees with high potential for leadership in a particular organisation are scarce. There is also some extrapolation from the use in such surveys of talent as a generic term for people and their skills to talent as a minority of employees with the potential for substantive advancement (exclusive TM). Differences in individual performance in organisations are plain to see but it is a considerable leap from this to say that only a small proportion of employees in an organisation are endowed with senior leadership potential.

\footnotetext{
Managing Talent: A Critical Appreciation, 1-6 Copyright $\odot 2020$ by Emerald Publishing Limited All rights of reproduction in any form reserved doi:10.1108/978-1-83909-093-620201002
} 
The fourth assumption seems the most vulnerable to empirical challenge. The evidence for the positive effects of TM on organisational performance, although it is beginning to emerge, remains at best modest (Glaister, Karacay, Demirbag, \& Tatoglu, 2018; Latukha \& Veselova, 2019; Son, Park, Bae, \& On, 2018) and in some cases is specious (Pfeffer \& Sutton, 2006). This is unsurprising, however, given methodological problems and the wide range of factors that affect performance over and above any direct or indirect effects that TM may have. However, rather than seek binary views on whether TM is beneficial or not, a more balanced approach is to identify the conditions under which TM has positive effects and the conditions under which it begins to harm people and organisations. Given the nature of the presumed link it will require a steady accumulation of evidence before a safe verdict can be reached. A related problem is that, while measures of individual and organisational performance are readily available, there is not yet a way of quantifying the extent that organisations actually implement anything resembling an accepted definition of TM in contrast to some variation of management training and development. The development of an index or scale that quantifies the extent to which TM occurs in an organisation (e.g., see Jayaraman, Talib, \& Khan, 2018) seems overdue. However, even this would not tell us whether talent pools really do contain people with on average more talent than the rest of the workforce.

Even if these assumptions are safe, then they play to a very instrumental view of the relationships between people and organisations (Painter-Morland, Kirk, Deslandes, \& Tansley, 2018). Exclusive TM draws us towards the psychology of corporate elites (Faulconbridge, Beaverstock, Hall, \& Hewitson, 2009; Mellahi \& Collings, 2010). Elites arise in societies in which some people posses more of something than others such as wealth, courage or educational privilege. Elites form to serve people with a particular resource or advantage which, in exclusive TM's case is, among other things, a talent for organisation, for getting noticed and for maintaining elevated status. The danger is that the members of elites start to define themselves as deserving of what they possess and come to see their elevated status, in this case as executives and would-be executives, as extensions of themselves. As Mills (1956, p. 14) pithily observed, 'People with advantages are loath to believe that they just happen to be people with advantages'. Elites come to believe strongly in their own capabilities and in the inability of people outside the elite to do what they can do.

Hence, the practice of exclusive TM attracts criticism for being divisive and for its potentially adverse effects on both the talented and the employees that talent systems overlook (De Boeck, Meyers, \& Dries, 2018; Kickuk, Brown, \& Ladkin, 2019; Pfeffer, 2001). Furthermore, search practices for executive talent stand accused of being gendered (Tienari, Meriläinen, Holgersson, \& Bendl, 2013) and the meaning of 'talent' in organisational contexts is, in practice, vague (Jooss, McDonnell, \& Burbach, 2019). The same can be said of 'talent management' which has come to mean almost anything. Managing talent is an attractive idea for simple, albeit questionable, reasons and the literature ranges from what is nothing more than essentially relabelling people as talent and Human Resource Management (HRM) as TM to exclusive/elitist approaches that seek 
to identify small cadres of high-potential employees and furnish them with accelerated and special development opportunities that the non-talented do not have. These opportunities typically include lengthy development programmes as part of a talent pool, exposure to executive time and attention, mentoring and working on high-status projects. This fluidity in how the field is interpreted has not helped to move it forward. As such, and in order to focus on a clearly defined field, unless otherwise stated this volume treats TM largely from an exclusive/ elitist perspective; namely the identification of pivotal roles in organisations, the development of small groups of employees that are credited with the potential to add distinctive value to organisations and the placement of high-potential people into pivotal roles (Collings, Cascio, \& Mellahi, 2017, p. 5).

Another feature is that the growing literature on TM has been swept along on a tide of executive faith in its powers with only slight regard given to its possible (and actual) pitfalls. These pitfalls have not received the consideration that they deserve and this is needed to provide a more comprehensive appreciation of what has become a widely used organisational initiative. This contribution to David Collings and Vlad Vaiman's series on TM attempts to tackle some of the concerns raised above and the issues arising from them. In doing so it takes a more critical view of organisational approaches to identifying, developing and deploying high-potential employees and to understanding why organisations are attracted to talent and in-turn to TM.

The relatively light treatment that TM has received so far from more critical perspectives (for an exception see Adamsen \& Swailes, 2019) represents a significant gap in the literature. We hope that this collection of chapters will help to narrow that gap and provide a convenient reference source that appeals to researchers, postgraduate students and practitioners who are looking for alternative treatments, understandings of and critical issues arising from managing talent in practice. The contributors to Managing Talent: A Critical Appreciation offer a range of perspectives that we hope will inform further research and practice surrounding the management of high-potential people.

In Chapter 1, Billy Adamsen takes a philosophical look at the meaning of talent. He highlights the vagueness of the term and corresponding implications for talent identification. In Chapter 2, Stephen Swailes explores the core assumption that the talented exist as a distinct organisational community. He shows how talent can be socially constructed and juxtaposes this with evidence for natural, innate talent. Some ethical implications arising from both social and innate formulations of talent are revealed and he considers whether it matters for Human Resource Development/HRM if talent is more socially constructed than real. The prospect of empty TM is developed and the chapter contextualises the treatments of talent and talent practice that follow.

In Chapter 3, Eva Gallardo-Gallardo reviews the TM literature and offers a critical reflection on the relevance (visibility and impact) of TM research. Although the field has evolved significantly, she concludes that current TM research is lost in and before translation and encourages self-examination and collaboration between the different stakeholders in order to overcome such issues. 
In Chapter 4, Barbara Zesik draws on her experience as an HR Director in international businesses and on her empirical research with actors in talent situations to explore the tensions between the rhetoric and reality of life in talent pools. Focussing on the relatively under-researched social and political aspects of managing talent and using seldom heard voices from people in talent programmes she illustrates how talent identification and management 'really works' and offers suggestions for better practice.

In Chapter 5, Suzanne Ross draws on her experience previously as a Talent Manager and now as a Leadership Consultant, Executive Coach and Senior Lecturer in Executive Education and applies her research on leadership derailment to TM. In particular, she addresses a research gap in TM concerning the high proportion of leaders that go on to derail. The derailment literature is, to date, disconnected from TM although central to the definition of leadership derailment is that derailed leaders were previously successful and had potential. She uses the notion of the 'accidental manager' to provide an example of where literature on TM and derailment converge as a key derailer characteristic is having an overly functional orientation. This maps neatly to the accidental manager concept and to the challenges that TM practitioners face in developing career pathways for expert/specialists beyond managerial roles. She argues that talent identification should take more account of derailment characteristics and suggests that there may be gender differences in how derailment characteristics are perceived.

In Chapter 6, Peter Bos, Marian Thunnissen and Katja Pardoen deal with the under-explored role of line managers in implementing TM processes. Reporting results from a quantitative study of 22 teams in a Dutch university following an inclusive TM path, they provide insights into the influence of the line manager's leadership style on employee perceptions of TM and their affective reactions, as well as the constraints in the line manager's role in executing TM. This helps to explain what happens in practice and how effective TM systems can be designed and implemented.

In Chapter 7, Lotte Holck and Iben Sandal Stjerne engage with the meaning and practical implementation of inclusive TM. In attempting to reduce inequalities, inclusive TM has moral advantages over exclusive TM and embodies a different conceptualisation of what talent means and focusses on a much wider employee group. They draw on the literature around workplace inclusion and highlight tensions arising when the inclusion of one person forces or at least pressures the exclusion of another. They report fieldwork in a Danish service company which is attempting to introduce a hybrid exclusive/inclusive TM strategy.

In Chapter 8, Beverly Dawn Metcalfe, Yasmeen Makarem and Fida Afouni examine how critical feminist organisation studies can shed light on the dominance of masculinist logics in theorising the theory and practice of TM and reveal opportunities to review TM systems that stress inclusion and equity. This is a timely attempt to draw out, extend and give emphasis and voice to what is silent or marginally present or ideologically represented in the current TM literature. They explore the masculinisation of talent, the marginalisation of gender and social differences and the elitism of the TM process, all of which ground current 
TM rhetoric. Their analysis draws on inclusive and exclusive strategies and their arguments favour reforming TM systems.

In Chapter 9, Deborah McPhee and Francine Schlosser contextually analyse extra-organisational macro factors of the recently legalised cannabis industry in Canada and their effect on the intra-organisational micro factors related to HRM activities. They demonstrate restraints and opportunities from the macro perspectives associated with government regulation, legalisation, legitimisation and reputation that impact the micro perspectives related to attraction, development and retention of key talent in this emerging industry.

\section{References}

Adamsen, B., \& Swailes, S. (Eds.). (2019). Managing talent: Understanding critical perspectives. Basingstoke: Palgrave Macmillan.

Collings, D. G., Cascio, W. F., \& Mellahi, K. (2017). Introduction. In D. G. Collings, K. Mellahi, \& W. F. Cascio (Eds.), The Oxford handbook of talent management (pp. 3-22). Oxford: Oxford University Press.

Collings, D. G., Mellahi, K., \& Cascio, W. F. (2019). Global talent management and performance in multinational enterprises: A multilevel perspective. Journal of Management, 45(2), 540-566.

De Boeck, G., Meyers, C. M., \& Dries, N. (2018). Employee reactions to talent management: Assumptions versus evidence. Journal of Organizational Behavior, 39(2), 199-213.

Faulconbridge, J. R., Beaverstock, J. V., Hall, S., \& Hewitson, A. (2009). The 'war for talent': The gatekeeper role of executive search firms in elite labour markets. Geoforum, 40(5), 800-808.

Glaister, A. J., Karacay, G., Demirbag, M., \& Tatoglu, E. (2018). HRM and performance The role of talent management as a transmission mechanism in an emerging market context. Human Resource Management Journal, 28(1), 148-166.

Grimland, S., Vigoda-Gadot, E., \& Baruch, Y. (2012). Career attitudes and success of managers: The impact of chance event, protean and traditional careers. International Journal of Human Resource Management, 23(6), 1074-1094.

Jayaraman, S., Talib, P., \& Khan, A. F. (2018). Integrated talent management scale: Construction and initial validation. SAGE Open, 8(3 July-September), 1-12, doi: $10.1177 / 2158244018780965$

Joo, H., Aguinis, H., \& Bradley, K. J. (2018). Not all nonnormal distributions are created equal: Improved theoretical and measurement precision. Journal of Applied Psychology, 102(7), 1022-1053.

Jooss, S., McDonnell, A., \& Burbach, R. (2019). Talent designation in practice: An equation of high potential, performance and mobility. International Journal of Human Resource Management, doi:10.1080/09585192.2019.1686651

Kickuk, A., Brown, L., \& Ladkin, A. (2019). Talent pool exclusion: The hotel employee perspective. International Journal of Contemporary Hospitality Management, 31(10), 3970-3991.

Latukha, M., \& Veselova, A. (2019). Talent management, absorptive capacity, and firm performance: Does it work in China and Russia. Human Resource Management, 58(5), 503-519.

Mellahi, K., \& Collings, D. G. (2010). The barriers to global talent management: The example of corporate elites in MNEs. Journal of World Business, 45(2), 143-149. 


\section{Stephen Swailes}

Meyers, M. C. (2019). The neglected role of talent proactivity: Integrating proactive behaviour into talent-management theorizing. Human Resource Management Review, 30(2), 100703. doi:10.1016/j.hrmr.2019.100703

Mills, C. W. (1956 [2000]). The power elite. Oxford: Oxford University Press.

Painter-Morland, M., Kirk, S., Deslandes, G., \& Tansley, C. (2018). Talent management: The good, the bad and the possible. European Management Review, 16(1), 135-146.

Pfeffer, J. (2001). Fighting the war for talent is hazardous to your organization's health. Organizational Dynamics, 29(4), 248-259.

Pfeffer, J., \& Sutton, R. I. (2006). Management half-truths and nonsense: How to practice evidence-based management. California Management Review, 48(3), 77-100.

Pluchino, A., Biondo, A. E., \& Rapisarda, A. (2018). Talent vs luck: The role of randomness in success and failure. Advances in Complex Systems, 21(3/4), 1-28.

SHRM. (2019). The global skills shortage. Society for Human Resource Management. Retrieved from www.shrm.org

Silzer, R., \& Church, A. H. (2009). The pearls and perils of identifying potential. Industrial and Organizational Psychology, 2(4), 377-412.

Son, J., Park, O., Bae, J., \& Ok, C. (2018). Double-edged effect of talent management on organizational performance: The moderating role of HRM investments. International Journal of Human Resource Management, doi:10.1080/09585192.2018.1443955

Tienari, J., Merilainen, S., Holgersson, S., \& Bendl, R. (2013). And then there were none: On the exclusion of women in processes of executive search. Gender in Management, 28(1), 43-62. 


\title{
Chapter 1
}

\section{Arbitrariness, Individuality, and the Absence of Work Identity in Talent Management}

\author{
Billy Adamsen
}

The semantic emptiness of the concept of talent has led to an arbitrary understanding of talent as something undefinable and associated with the individuality of talent and dissociated from the work identity. This dissociation between talent and work identity in talent management in part accounts for the arbitrariness in talent recruitment and selection, which is the focus of this short chapter. Using an interdisciplinary perspective that draws on insights from philosophy, linguistics, psychology, and sociology, this chapter conducts a philosophical investigation of the concept of talent and its dissociation from work identity and seeks to explain the impacts on talent recruitment and selection.

$* * *$

In the preface to Tractatus Logico-Philosophicus, Wittgenstein (2010) claims that the method for formulating the problems of philosophy 'rest on a misunderstanding of the logic of our language' (p. 23). Since Wittgenstein realised this misunderstanding, he was convinced that he was the only philosopher who could identify (formulate) the true problem of philosophy. Solving this problem would render philosophy a discipline of the past, and science could fully take over, allowing Wittgenstein to retire, which he did for a while.

This problem of philosophy is what the Tractatus Logico-Philosophicus addressed. Wittgenstein (2010) believed that the single, primary problem of philosophy arose from a limitation of thinking or more specifically,

The book will, therefore, draw a limit to thinking, or rather - not to thinking, but to the expression of thoughts; for, in order to draw a limit to thinking we should have to be able to think both sides of the limit (we should, therefore, have to be able to think what cannot be thought). The limit can, therefore, only be drawn in language and what lies on the other side of the limit will be simply nonsense. (p. 23)

\footnotetext{
Managing Talent: A Critical Appreciation, 7-12 Copyright $\odot 2020$ by Emerald Publishing Limited All rights of reproduction in any form reserved doi:10.1108/978-1-83909-093-620201003
} 
Worded differently, this limit in philosophy can only be identified using spoken language with 'what can be said at all, can be said clearly; and whereof one cannot speak, thereof one must be silent' (Mualem, 2002; Wittgenstein, 2010, p. 23).

What Wittgenstein meant has been discussed for decades. When asked to clarify his meaning, he often became frustrated because he believed his description of the problem was obvious (Ground \& Flowers, 2015; Mualem, 2002). However, as with much of what Wittgenstein wrote, his meaning was not obvious. As such, the philosophical club, the Vienna Circle led by Bertrand Russell, stated that philosophy and science should focus on ideas that could be measured, categorised, and spoken about in a referential observable way (Mualem, 2002). Wittgenstein, who was also a member of the Circle, disagreed with Russell and other members because such a belief contrasted with his claims regarding philosophy.

Instead, it appears what he meant was that some matters, for instance, God and feelings, cannot be discussed clearly and unambiguously. Despite such matters being important to him, he considered them to belong 'on the other side of the limit' and as something that we cannot talk about in an unambiguously and referential way - at least not when it comes to the expression of propositions (Mualem, 2002).

\section{Talent Whereof One Cannot Speak, Thereof One Must Be Silent}

Since the establishment of talent management as an independent discipline in the late 1990s, the very foundation of the discipline, talent and the existence of talent in the actual world, is a matter that lies beyond the limit - 'whereof one cannot speak, thereof one must be silent'. Lewis and Heckman (2006) noted an evident lack of semantic clarity in the compound phrase 'talent management' and Tansley (2011) demonstrated how the meaning of the term 'talent' itself is blurry and difficult to define.

Adamsen (2016, p. 122) considered the blurriness of the meaning of 'talent' and demonstrated that the term had become an empty signifier of which one cannot speak. The continued use of the term has led to 'talent' becoming a magic word rather than a lexical one and 'talent' is used to symbolise faith in something or someone rather than encapsulate actual knowledge (Adamsen, 2014). The practical consequences of using talent as an empty signifier leads to management practice, identification, recruitment, and selection of talent, being impacted by a subjective bias rather than a factual understanding:

Empty signifiers of this kind function to express the speaker's belief in something or someone, belief that - and this is crucial is not grounded in evidence-based argument of the kind favored by science. This would degrade or reduce its semiotic significance to something mundane and concrete. These two characteristics of empty signifiers - referential emptiness and magical or religious semantic significance - mean that they are symbols of collective faith, and refer to cultural abstracta, religious wisdom, or adagia of historical events. This is appropriate and important for words 